\title{
High-Performance Metal-Supported Solid Oxide Fuel Cells by Advanced Cathode Processing
}

\author{
D. Udomsila ${ }^{a, b}$, D. Roehrens ${ }^{a, b}$, N.H. Menzler ${ }^{b}$, C. Bischof ${ }^{a}$, L.G.J. de Haart ${ }^{b}$, A.K. Opitz ${ }^{a, c}$, \\ O. Guillon ${ }^{\mathrm{b}, \mathrm{d}}$ and M. Bram ${ }^{\mathrm{a}, \mathrm{b}}$
}

${ }^{a}$ Christian Doppler Laboratory for Interfaces in Metal-Supported Electrochemical Energy Converters; d.udomsilp@fz-juelich.de

${ }^{\mathrm{b}}$ Forschungszentrum Jülich $\mathrm{GmbH}$, Institute of Energy and Climate Research, 52425 Jülich, Germany

${ }^{\mathrm{C}}$ TU Wien, Institute of Chemical Technologies and Analytics, Getreidemarkt 9/164-EC, 1060 Vienna, Austria

${ }^{d}$ Jülich Aachen Research Alliance: JARA-Energy

\begin{abstract}
$\mathrm{La}_{0.58} \mathrm{Sr}_{0.4} \mathrm{Co}_{0.2} \mathrm{Fe}_{0.8} \mathrm{O}_{3-\delta}$ (LSCF) cathodes on metal-supported solid oxide fuel cells (MSCs) were fabricated by a novel sintering approach and electrochemically tested in single-cell measurements. The sintering of cathodes on complete cells was performed under argon atmosphere at $950{ }^{\circ} \mathrm{C}$ in order to prevent strong oxidation of the metallic support. During this sintering process, a phase decomposition of LSCF occurred, which was found to be reversible upon heating in ambient air. The observed performance increase of MSCs with cathodes sintered ex situ, compared to cells processed under standard conditions, revealed a beneficial effect of the increased sintering temperature on cell performance. At $750{ }^{\circ} \mathrm{C}$ and $0.7 \mathrm{~V}$ a current density of $0.96 \mathrm{~A} / \mathrm{cm}^{2}$ was achieved. A stronger adherence of the cathodes sintered ex situ was observed after single-cell measurements. In additional experiments, $\mathrm{La}_{0.58} \mathrm{Sr}_{0.4} \mathrm{CoO}_{3-\delta}$ (LSC) was applied as an alternative cathode for MSCs. These cells were activated in situ at $850^{\circ} \mathrm{C}$ due to the lower thermochemical stability of LSC and indicated potential for further improvement of the cell performance. The successful electrochemical characterization of the cells with LSCF cathodes sintered ex situ confirmed the applicability of the novel sintering procedure as well as the improved adherence achieved by the optimized processing.

\section{Introduction}

Solid oxide fuel cells (SOFCs) have been the subject of intensive research in recent decades, resulting in considerable improvement to performance and lifetime of cells and stacks (1-5). Different designs in terms of geometrical setup of the cell and the supporting structure have been developed. The first significant progress was achieved with the tubular cell design, as introduced by Westinghouse in the 1980s (2, 6, 7). Pursuing development of the planar cell design revealed the potential of high power densities
\end{abstract}


achievable in this setup. Initial cells were usually constructed as electrolyte-supported cells (ESCs), with porous electrodes on a thick (>>100 $\mu \mathrm{m})$, dense electrolyte. This design requires a high operating temperature in the range of $800-1000{ }^{\circ} \mathrm{C}$ due to the increased ohmic resistance of the electrolyte at lower temperature $(8,9)$. Subsequently, development of electrode-supported concepts was intensified as they offer the potential to decrease the cell operating temperature by applying thin-film electrolytes. Furthermore, inexpensive metallic materials were introduced as interconnectors at temperatures $<850{ }^{\circ} \mathrm{C}(10-13)$. At Forschungszentrum Jülich ("JÜLICH"), the concept of planar anode-supported cells (ASCs) has been primarily developed (14-19). Another related cell concept is metalsupported solid oxide fuel cells (MSCs), utilizing a porous metal as the mechanical support. Recently, MSC research has become one of the hot topics of current SOFC development $(13,20-27)$. Replacing the ceramic support by a metal support is expected to result in a substantial improvement in the robustness of these cells with respect to vibrations, fast thermal cycles and redox cycles $(4,28)$. Therefore, the MSC design is especially promising for use in mobile applications, where short startup times and ruggedness are crucial for a successful implementation. Moreover, the use of cheaper ferritic steel instead of ceramic components in the supporting structure, enables a decrease of system costs (21). Another important advantage of an MSC - compared to other fuel cell concepts, such as polymer electrolyte membrane (PEM) types - is its fuel flexibility. Whereas PEMs require high-purity $\mathrm{H}_{2}$, MSCs can be operated with a wide range of available fuels using existing infrastructures for the supply of, for example natural gas, ethanol or diesel $(4,29-31)$. Together with legislation such as the anti-idling laws in the US, these properties make MSCs the fuel cell of choice for world market leaders such as AVL List (Austria) for use in auxiliary power units (APUs) in heavy-duty vehicles (29). Plansee SE ("PSE", Austria) has been developing an MSC design in close cooperation with Forschungszentrum Jülich GmbH (Germany) since 2008 (5, 26, 27, 30, 32). The design of the electrochemically active layers is based on the well-known setup of ASCs fabricated in JÜLICH since the early 1990s (17-19, 33). Nonetheless, the specific processing of the functional layers of MSCs has to be adapted to the requirements of the porous metal support. Hence, anode sintering is performed under reducing $\mathrm{H}_{2}$ atmosphere. Metallic Ni powder was used as the raw material for the Ni/8YSZ anode cermet, in contrast to $\mathrm{NiO}$ which is usually applied in ASC processing. Recently, also the ceramic 8YSZ phase was replaced by GDC as the ion-conducting material of the anode, in order to increase the performance as well as the sulfur tolerance of MSCs (33-35). The electrolyte and the diffusion barrier layers are applied by magnetron sputtering, a physical vapor deposition (PVD) process $(5,36,37)$. A considerable difference to the fabrication of ASCs is the absence of a cathode sintering step in the current MSC processing. In the established ASC or ESC fabrication, the cathode is usually sintered before stack operation ("ex situ sintering") at temperatures above $1000^{\circ} \mathrm{C}(15,16,18)$, in order to achieve sufficient bonding between cathode and electrolyte and to obtain the desired microstructure. However, the well-known cathode processing of ASCs is not suitable for MSC production. This is due to severe oxidation of the metal substrate and of the Ni phase in the Ni/8YSZ anode cermet if thermal treatment is performed in ambient air. On the other hand, the currently used cathode material, LSCF, decomposes if exposed to reducing 
atmosphere at high temperature (38-41). Therefore, the cathode is utilized as a green layer in many state-of-the-art MSCs and activated in situ during the onset of operation (26, $32,35,42-44)$. It should be mentioned here, that in addition to our process, there are several other approaches to address the issue of cathode fabrication throughout the MSC community. Perovskite type mixed ionic electronic conductors, mostly of the ( $\mathrm{La}, \mathrm{Sr})(\mathrm{Co}, \mathrm{Fe}) \mathrm{O}_{3-\delta}$ system, are a commonly used active material for oxygen reduction. Besides the presented approach of printing and subsequent in situ activation, methods like plasma spraying or infiltration of active components into porous backbone structures and other processes can be applied and express their specific challenges $(21,22,45)$. MSC concepts of various manufacturers and recent progress in MSC technology were recently reviewed by Krishnan (46). A drawback of the in situ activation procedure is the decrease in mechanical stability and adherence as a result of the low sintering temperature of $850^{\circ} \mathrm{C}$, which is limited by the maximum temperature during startup of the stack. As a result, cathode failure can often be observed after MSC operation and is assumed to significantly contribute to the rapid degradation of cells and stacks. Thus, optimization of the cathode processing of MSCs was the goal of the present study to achieve improved reliability of MSCs. For this purpose, two main approaches were considered to be most promising: i) the development of an ex situ sintering procedure for MSC cathodes in combination with an increased sintering temperature in order to achieve stronger cathode adherence; and ii) the improvement of the cathode adherence after in situ activation by the addition of sintering additives, optimized raw materials or interface optimization. This paper focuses on the first approach, using to a large extent the same materials and similar preparation techniques as applied in the standard fabrication of PSE metal-supported cells. Detailed investigation of the phase stability and sintering behavior of LSCF in various atmospheres provided the basis for optimizing cathode processing. By observing the resulting mechanical stability/integrity of the cathode layers on MSC half-cells, sintered ex situ under different atmospheres and temperatures, a reliable fabrication procedure was developed. Electrochemical performance was investigated by single-cell measurements in order to assess the potential of the novel processing route.

\section{Experimental}

\subsection{Sample Preparation}

$\mathrm{La}_{0.58} \mathrm{Sr}_{0.4} \mathrm{Co}_{0.2} \mathrm{Fe}_{0.8} \mathrm{O}_{3-\delta}$ (LSCF) and $\mathrm{La}_{0.58} \mathrm{Sr}_{0.4} \mathrm{CoO}_{3-\delta}$ (LSC) powders were synthesized inhouse by the spray drying method described elsewhere (47). Subsequently, the powders were calcined at $900{ }^{\circ} \mathrm{C}$, wet milled to an average particle size of $d_{50}=0.8 \pm 0.1 \mu \mathrm{m}$, with $\mathrm{d}_{10}=0.6 \mu \mathrm{m}$ and $\mathrm{d}_{90}=1.1 \mu \mathrm{m}$, and dried at $70{ }^{\circ} \mathrm{C}$. The obtained powders provided the starting material for analyses of properties such as sintering activity, phase composition and phase stability. In the next step, the materials were applied to investigate their performance as MSC cathodes. Initial experiments were conducted on uniaxially pressed pellets (100 MPa, $120 \mathrm{~s}, 8 \mathrm{~mm}$ diameter) for dilatometry and screen-printed layers. In order to fabricate cathode layers by screen printing, a paste was prepared from milled LSCF and LSC powders, terpineol (Thinner 8250, Du Pont, UK) as a solvent and ethyl 
cellulose binder (CAS 9004-57-3, Sigma-Aldrich, Germany) (48). The layers were printed using a semi-automatic screen printer (Ekra E1, Ekra Automatisierungssysteme GmbH, Germany). The resulting thickness of the dried ("green", i.e. not sintered) layers was approx. $50 \mu \mathrm{m}$.

Model samples were prepared for initial experiments using commercially available 8YSZ electrolyte substrates ( $d=200 \mu \mathrm{m}$, Kerafol, Germany), coated with a GDC (gadolinium doped ceria $-\mathrm{Ce}_{0.8} \mathrm{Gd}_{0.2} \mathrm{O}_{2-\delta}$ ) diffusion barrier by PVD. Subsequently the cathode layers were screen printed. Some of these layers were printed directly on the electrolyte substrates to investigate the adherence and phase stability resulting from different conditions during thermal treatment. For single-cell testing, MSC half-cells consisting of the metallic ITM substrate (Plansee SE) (5), Ni/8YSZ anode, 8YSZ electrolyte and GDC diffusion barrier were provided by Plansee SE. The supporting ITM material is an oxide dispersed strengthened (ODS) alloy, containing $26 \% \mathrm{Cr}$ as well as minor amounts of Mo, $\mathrm{Ti}$ and $\mathrm{Y}_{2} \mathrm{O}_{3}$. A thin $(\approx 1 \mu \mathrm{m})$ GDC diffusion barrier layer is applied by a PVD process in order to prevent interdiffusion between the support ( $\mathrm{Cr}, \mathrm{Fe})$ and the anode (Ni). The anode is applied by screen printing, as a functionally graded structure, using different particle sizes of the Ni and YSZ raw materials. The three layers of the anode structure stepwise reduce the pore size by using smaller particles. This prevents significant infiltration of small anode particles into the large pores of the substrate and provides the desired large surface area of the electrochemically active anode layer. Simultaneously the surface quality is improved, enabling the deposition of the thin, gastight electrolyte layer. This YSZ electrolyte and the air side GDC DBL are applied by PVD. Detailed information of the processing steps was reported elsewhere $(26,32,37,49)$. Cathode layers of $40 \times 40 \mathrm{~mm}^{2}$ were screen printed, using the equipment mentioned above. A schematic of the cell setup, including the thickness of the applied layers, is shown in Figure 1.

\subsection{Sample Characterization}

Different experimental conditions were chosen to investigate the phase stability of the LSCF cathode material. Ambient air and atmospheres with reduced oxygen partial pressure were applied in order to determine the influence on the cathode properties resulting from ex situ sintering under low $\mathrm{p}_{\mathrm{O} 2}$ in comparison to traditional sintering in air. Dry $\operatorname{Ar}(5.0)$ (i.e. $99.999 \%$ purity argon with $<2 \mathrm{ppm} \mathrm{O}_{2}$ ) and $\mathrm{Ar} / 2.9 \% \mathrm{H}_{2}\left(\mathrm{p}_{\mathrm{O} 2} \approx 10^{-20}\right.$ bar) were chosen for experiments in low $\mathrm{p}_{\mathrm{O} 2}$ environment. At the sintering furnaces in the current state, we used gases which are usually accessible in our labs. $\operatorname{Ar}(5.0)$ for simulating sintering in inert atmosphere, $\mathrm{Ar} / 2.9 \% \mathrm{H}_{2}$ for simulating harsh conditions, which might occur in the case of very pronounced oxygen-getter effect of a porous metal with large surface area. Thermal treatment of the samples was carried out at temperatures in the range of 850 to $1040{ }^{\circ} \mathrm{C}$. These temperatures represent the prevalent conditions during thermal treatment in either the in situ activation of state-of-the-art MSCs $(33,50)$ or the established sintering procedure of ASCs with a PVD-GDC barrier layer (36). The experiments were conducted in a tube furnace $\left(\mathrm{Al}_{2} \mathrm{O}_{3}\right.$ tube, heated length $750 \mathrm{~mm}$, diameter $80 \mathrm{~mm}$ ). The gas supply of $\mathrm{Ar}$ or $\mathrm{Ar} / \mathrm{H}_{2}$ was varied in the range from 185 to 
$840 \mathrm{Sml} / \mathrm{min}$ and the resulting $\mathrm{p}_{\mathrm{O} 2}$ was measured using a heated oxygen sensor (type GSM, Metrotec GmbH, Germany) at the outlet of the furnace.

\subsubsection{Sintering Behavior}

The sintering activity of the starting powders was analyzed on pressed pellets using a Netsch DIL 402C dilatometer. Measurements were conducted at 850,950 and $1040{ }^{\circ} \mathrm{C}$ with a dwell time of $5 \mathrm{~h}$. Heating/cooling rates were set to $5 \mathrm{~K} / \mathrm{min}$. The influence of the sintering atmosphere on the sintering activity was evaluated by applying air ( $\mathrm{p}_{\mathrm{O} 2}=0.21$ bar), $\operatorname{Ar}(5.0)\left(\mathrm{p}_{\mathrm{O} 2} \approx 10^{-5} \mathrm{bar}\right)$, and $\mathrm{Ar} / 2.9 \% \mathrm{H}_{2}\left(\mathrm{p}_{\mathrm{O} 2} \approx 10^{-20}\right.$ bar $)$ during dilatometry.

\subsubsection{Phase Stability}

Phase composition analysis was carried out using ambient temperature XRD (D4 Endeavor, Bruker Corp., USA) as well as high-temperature XRD (HT-XRD) (Empyrean, PANalytical $\mathrm{GmbH}$, Germany). In this study, besides sintered pellets, screen-printed LSCF layers sintered on 8YSZ substrates as well as on MSC half-cells were used.

For the in situ observation of phase transformations by HT-XRD, a screen-printed LSCF cathode layer was sintered for $3 \mathrm{~h}$ at $950{ }^{\circ} \mathrm{C}$ under an $\mathrm{Ar} / 2.9 \% \mathrm{H}_{2}$ atmosphere. After sintering, the sample was directly transferred to the HT-XRD setup. The first measurement was conducted at ambient temperature in order to identify the initial phase composition. Subsequently, the sample was heated at a rate of $3 \mathrm{~K} / \mathrm{min}$ to $500{ }^{\circ} \mathrm{C}$. During a dwell time of $1 \mathrm{~h}$, three XRD measurements of 20 min each were carried out. The same procedure was applied at a temperature of $600^{\circ} \mathrm{C}$ and at subsequent steps of $50 \mathrm{~K}$ up to $800{ }^{\circ} \mathrm{C}$. At the final temperature of $850^{\circ} \mathrm{C}$, three measurements of $1 \mathrm{~h}$ each were performed. Multiple measurements at each isothermal dwell time were performed in order to observe timedependent changes of the phase composition. If no changes were observed between the three measurements, the intensities of the three measurements can be added up and plotted as one measurement of $1 \mathrm{~h}$ duration (which therefore reveals a higher intensity).

\subsubsection{Electrochemical Characterization}

Optimized processing parameters, derived from the various characterizations, were chosen for the fabrication of complete MSCs for electrochemical single-cell measurements. Cells with total dimensions of $50 \times 50 \mathrm{~mm}^{2}$ and an active cathode area of $40 \times 40 \mathrm{~mm}^{2}$ were tested at JÜLICH. Round button cells of $35 \mathrm{~mm}$ total diameter and $20 \mathrm{~mm}$ diameter cathode area were tested at PSE. The cells were mounted onto the test setup using a glass sealant to ensure proper separation of the gas compartments. Heating rates were set to $1-2 \mathrm{~K} / \mathrm{min}$. After debinding of the glass sealant and the cathode at $350{ }^{\circ} \mathrm{C}$, the setup was heated to $850^{\circ} \mathrm{C}$, at which crystallization of the glass sealant takes place. Subsequently, the electrochemical characterization was performed in the temperature range of 850 to $650^{\circ} \mathrm{C}$. During the measurements at JÜLICH, the flow rates for the gas supply were set to $533 \mathrm{sccm} \mathrm{H}_{2}$ and $667 \mathrm{sccm}$ air, respectively. This corresponds to flow rates of $33 \mathrm{ml} /\left(\mathrm{cm}^{2} \cdot \mathrm{min}\right) \mathrm{H}_{2}$ and $41 \mathrm{ml} /\left(\mathrm{cm}^{2} \cdot \mathrm{min}\right)$ air. The intention of 
normalizing the applied gas flow by the active cathode area $\left(\mathrm{cm}^{-2}\right)$ was to facilitate the comparison between results obtained on different cell geometries. The applied flow rates were derived from previous MSC cell tests conducted with the same setup. Considering the maximum current densities of about $1.2 \mathrm{~A} / \mathrm{cm}^{2}$ at $850{ }^{\circ} \mathrm{C}$ obtained in those tests $(33$, $35)$, one can calculate the resulting fuel and air utilizations to roughly $25 \%$ for $\mathrm{H}_{2}$ and $50 \%$ for $\mathrm{O}_{2}$ (from air), respectively. These utilizations are comparably high for single cell measurements, but acceptable to avoid pronounced concentration limitations. Measurements of the current-voltage curves were performed from OCV to about $0.65 \mathrm{~V}$ by increasing the current density in steps of $25-30 \mathrm{~mA} / \mathrm{cm}^{2}$ every $30-60 \mathrm{~s}$. At PSE, different flow rates were applied in order to evaluate the influence of the supplied amount of gas. $A$ previous investigation of the influence of testing parameters on the observed cell performance of state-of-the-art MSCs by PSE (to be published) revealed no significant performance improvement when the flow rate of $\mathrm{H}_{2}$ was increased to more than $100 \mathrm{sccm}$, i.e. $32 \mathrm{ml} /\left(\mathrm{min} \mathrm{cm}^{2}\right)$ for a button cell with $3.14 \mathrm{~cm}^{2}$ active area. The amount of air supplied to the cell was found to have only a slight influence on cell performance if the flow rate exceeded $126 \mathrm{sccm}$ or $40 \mathrm{ml} /\left(\operatorname{min~} \mathrm{cm}^{2}\right)$. These values, as well as the maximum current densities of $1.2 \mathrm{~A} / \mathrm{cm}^{2}$, are in the range of the flow rates used at JÜLICH. In this work, additional measurements were conducted at PSE with considerably increased gas flow rates of $200 \mathrm{sccm}$, i.e. $63 \mathrm{ml} /\left(\operatorname{min~} \mathrm{cm}^{2}\right) \mathrm{H}_{2}$ and $600 \mathrm{sccm}$, i.e. $190 \mathrm{ml} /\left(\mathrm{min} \mathrm{cm}^{2}\right)$ air for comparison. This is related to the anticipated higher performance of cells with LSC cathode. The maximum current of the test bench is $5 \mathrm{~A}\left(1.6 \mathrm{~A} / \mathrm{cm}^{2}\right)$. If this current is reached, the set values correspond to a fuel and air utilization of $17 \%$ and $15 \%$, respectively. At these utilizations one can assume so called "flooded conditions", which means there is no influence from the gas concentrations.

\subsubsection{Microstructural Characterization}

The microstructure of the screen-printed cathode layers resulting from different sintering temperatures and sintering atmospheres was investigated by SEM (Ultra 55, Zeiss, Germany). Moreover, additional information regarding the quality of bonding between the cathode layer and the diffusion barrier was obtained from SEM images.

\section{Results and Discussion}

\subsection{Sintering Behavior}

Initial experiments for investigating the sintering behavior of LSCF were reported in a previous article (51). As expected, sintering activity of the mixed ionic electronic conducting (MIEC) material was found to considerably increase with increasing temperature. Additionally, further increased sintering activity, compared to sintering in air, was observed when the oxygen partial pressure was reduced during the thermal treatment by using an Ar atmosphere ( $\mathrm{p}_{\mathrm{O} 2} \approx 10^{-5} \mathrm{bar}$ ). Therefore, an Ar atmosphere during a cathode sintering step might not only prevent detrimental oxidation of the metal substrate but would also support the bonding between the diffusion barrier layer and cathode due to the higher 
sintering activity. For comparison, the sintering behavior of LSC was also evaluated by dilatometry. The shrinkage curves of LSC and LSCF at $950^{\circ} \mathrm{C}$ in ambient air are shown in Figure 2. For comparison, Figure 3 shows the curves measured in argon. LSC exhibits a higher coefficient of thermal expansion (slope during cooling) and slightly higher shrinkage during sintering in air than LSCF. An increased sintering activity under argon atmosphere was obtained for both materials, although the effect was more pronounced for LSC. The observed differences are considered to result from the material properties, as the determined powder particle sizes were similar. These results indicate that sufficient bonding and a suitable microstructure for an LSC cathode may be obtained at a slightly lower temperature compared to LSCF. Nonetheless, for initial experiments on LSC cathodes the same sintering conditions were chosen, as the differences are small.

\subsection{Phase Stability under Reducing Conditions}

In the previously reported work, it was found that screen-printed layers exhibit slightly higher sensitivity regarding the onset of phase decomposition compared to pressed pellets, which were used for dilatometry measurements and subsequently analyzed by XRD (51). It was concluded that, due to the high porosity and high specific surface area, the apparent atmosphere can penetrate the thin cathode layer and cause significantly more pronounced phase transformation. In contrast, for the pressed samples where porosity is drastically reduced, the critical oxygen content of the sintering atmosphere is shifted to lower values (51). Hence, further investigation of the phase stability was preferentially conducted on screen-printed layers as they correspond more closely to the real application.

Additional experiments revealed that the reversibility of the phase transformation went further than initially expected. In the sintering process of an MSC, the oxygen partial pressure of the argon atmosphere will be further reduced to $\mathrm{p}_{\mathrm{O} 2}<10^{-6}$ bar by oxidation of the ITM substrate. However, the exact influence of the metallic substrate is difficult to predict under flowing gas, i.e. non equilibrium conditions. For this reason, the phase stability of LSCF was investigated under an even stronger reducing atmosphere in order to simulate the most challenging conditions. $\mathrm{Ar} / 2.9 \% \mathrm{H}_{2}$ with $\mathrm{p}_{\mathrm{O} 2} \approx 10^{-20}$ bar was used as a model gas for these experiments. As expected, LSCF layers sintered under $\mathrm{Ar} / \mathrm{H}_{2}$ at $900{ }^{\circ} \mathrm{C}$ showed strong phase decomposition (Figure 4, bottom). Decomposition of LSCF to tetragonal $\mathrm{LaSr}(\mathrm{Co} / \mathrm{Fe}) \mathrm{O}_{4}, \mathrm{Co}, \mathrm{Fe}$, and $\mathrm{La}_{2} \mathrm{O}_{3}$ was observed, while the perovskite phase of LSCF disappeared completely. Even after this very severe phase decomposition, according to the $\mathrm{XRD}$ results, a re-oxidation treatment at $800^{\circ} \mathrm{C}$ in ambient air led to a fully reversible transformation back to $(\mathrm{La}, \mathrm{Sr})(\mathrm{Co}, \mathrm{Fe}) \mathrm{O}_{3}$ (Figure 4, top). Moreover, on a macroscopic scale, the integrity of the cathode layer was maintained during all thermal treatments and associated phase changes. This behavior differs considerably from that described in the recent literature, where Niedrig et al. (41) report irreversible decomposition of pressed LSCF powder compacts and related structures under oxygen partial pressures of $10^{-13}$ bar and $900^{\circ} \mathrm{C}$. In contrast, Hashimoto et al. (40) observed reversible phase transformations on the stoichiometric LSCF powder at temperatures up to $800^{\circ} \mathrm{C}$ and $10^{-13}$ bar without detecting the formation of $\mathrm{La}_{2} \mathrm{O}_{3}$. Ovenstone et al. (52) 
investigated the phase stability of materials from the (La,Sr) $\mathrm{CoO}_{3}$ group in a $\mathrm{N}_{2} / 4 \% \mathrm{H}_{2}$ mixture and found a complete decomposition of the perovskite structure into single oxides, which was reported to be fully reversible upon heating to $1000{ }^{\circ} \mathrm{C}$ in ambient air. On a related $(\mathrm{Ba}, \mathrm{Sr})(\mathrm{Co}, \mathrm{Fe}) \mathrm{O}_{3-\delta}$ structure, Ovenstone et al. (53) reported complete decomposition and full reversibility of the phase changes, but also observed microstructural disruption of dense samples after re-oxidation. Similar damage of sintered dense bodies was reported by Tai et al. (54) for $(\mathrm{La}, \mathrm{Sr})(\mathrm{Co}, \mathrm{Fe}) \mathrm{O}_{3-\delta}$. Therefore, in our study, the observed mechanical integrity of the sintered and re-oxidized LSCF cathode layer is a remarkable characteristic, though it does not directly imply a sufficient electrochemical activity and performance. In general, it is known that decomposition of LSCF and related structures under low $\mathrm{p}_{\mathrm{O} 2}$ conditions proceeds through several steps with primary decomposition products mostly being $\mathrm{AB}_{2} \mathrm{O}_{4}$ type structures. The final set of products consists of metals and binary oxides. (40,52, 55-57) Accurate determination of the partial pressures at which the onset of phase changes at a given temperature occur, is difficult. Therefore the obtained values depend on the measurement technique used and might differ between the investigations. (41) The formation of the intermediate decomposition products at higher $\mathrm{p}_{\mathrm{O} 2}$ needs to be considered already around $10^{-6}$ bar and $800^{\circ} \mathrm{C}(40)$. LSC which exhibits a lower stability compared to Fe containing compositions is reported to decompose at oxygen partial pressures as low as $10^{-5}$ bar and $800^{\circ} \mathrm{C}(58)$.

In order to better understand this recombination of LSCF, in situ observation of the reversible phase transformation from the decomposition products back to the LSCF perovskite structure was conducted by HT-XRD. At all temperatures except for the 700 and $750^{\circ} \mathrm{C}$ step, no differences were observed between the three scans during each isothermal dwell time of one hour. Accordingly, the intensities of these measurements were added up as described in Section 2.2.2. At 700 and $750{ }^{\circ} \mathrm{C}$, very slight changes were observed during the dwell time and only the final measurement (minutes 40 to 60) was considered in the graph. The results of the HT-XRD are summarized in Figure 5. The initial RT measurement confirmed the decomposition of LSCF to $\mathrm{LaSr}(\mathrm{Co} / \mathrm{Fe}) \mathrm{O}_{4}, \mathrm{Co}$, Fe, and $\mathrm{La}_{2} \mathrm{O}_{3}$. During the measurements with increasing temperature up to $650{ }^{\circ} \mathrm{C}$, a slight decrease of the $\mathrm{LaSr}(\mathrm{Co} / \mathrm{Fe}) \mathrm{O}_{4}$ Bragg peak intensity can be observed as well as a corresponding increase of the peaks identified as LSCF perovskite. When the temperature is further increased to $700{ }^{\circ} \mathrm{C}$, also the peak intensity of $\mathrm{La}_{2} \mathrm{O}_{3}$ starts to decrease. After $1 \mathrm{~h}$ at $750{ }^{\circ} \mathrm{C}$, the obtained diffraction pattern no longer indicated the presence of $\mathrm{La}_{2} \mathrm{O}_{3}$. At $800^{\circ} \mathrm{C}$, it can be identified clearly as LSCF perovskite and the substrate materials $8 \mathrm{YSZ}$ and GDC. Notable differences between the three subsequent measurements at constant temperature only occurred at $700^{\circ} \mathrm{C}$ and $750{ }^{\circ} \mathrm{C}$. At both temperatures, the Bragg peak intensities of the decomposition products decrease within the dwell time, whereas the intensity of LSCF peaks increased. As expected, the observed changes are more pronounced at the higher temperature. From the results presented here, it can be concluded that during operation of an MSC cathode in ambient air at $750{ }^{\circ} \mathrm{C}$ or $800{ }^{\circ} \mathrm{C}$ the reversible phase transformation back to the LSCF perovskite structure and the complete dissolution of $\mathrm{La}_{2} \mathrm{O}_{3}$ is expected to take place, leading to the evolution of the desired perovskite phase, which is phase-pure with respect to XRD. 
Investigation of the phase stability of LSC was conducted in Ar atmosphere. As expected, the results revealed a stronger susceptibility with respect to decomposition under reducing conditions. LSC layers screen printed on electrolyte substrates and sintered under moderately low $\mathrm{p}_{\mathrm{O} 2}$ in $\mathrm{Ar}$ decomposed to $\mathrm{LaSrCoO}_{4}$ and $\mathrm{CoO}$. No remaining perovskite structures were observed. After sintering an LSC cathode on an MSC under Ar atmosphere, the layers displayed a color change from black to a light gray color, indicating the pronounced formation of $\mathrm{La}_{2} \mathrm{O}_{3}$. XRD analysis of the layer confirmed this assumption (diffraction pattern not shown here). These results suggest that LSC is significantly more sensitive to reducing atmosphere during thermal treatment. Therefore, ex situ sintering under Ar is more likely to induce failure of LSC cathodes compared to LSCF.

\subsection{Stability of Ex Situ Sintered LSCF and LSC Cathodes Stored in Ambient Air}

A critical issue in the procedure of developing an ex situ sintering route for MSC full-cells is the resulting cathode layer stability. As observed in the previous publication (51), slight changes in processing conditions may lead to failure of the cathode layers. Therefore, further investigation focused on identifying the cause of failure. The derived sintering conditions of $950{ }^{\circ} \mathrm{C}$ and argon atmosphere were applied to complete MSCs. For sintering, the argon flow rate as well as the loading of the furnace (number of cells per run) was varied. After sintering, the resulting layer properties were observed. The layers initially undamaged after sintering subsequently failed during storage of the samples in ambient air at room temperature. It was observed that failure occurred earlier if the flow of argon during sintering was low, or many cells were sintered in the same run. XRD analysis of the phase composition of failed layers revealed the presence of $\mathrm{La}(\mathrm{OH})_{3}$ and $\mathrm{La}_{2} \mathrm{O}_{3}$. This result indicates that a critical point is reached if the oxygen content of the atmosphere during sintering is lowered to the point where $\mathrm{La}_{2} \mathrm{O}_{3}$ is formed. If free $\mathrm{La}_{2} \mathrm{O}_{3}$ is present in a produced layer, it is likely to damage the layer due to pronounced volume expansion resulting from the uptake of humidity from air and the corresponding formation of $\mathrm{La}(\mathrm{OH})_{3}$ $(59,60)$. It was concluded that by increasing the amount of ITM support material in the process, the oxygen partial pressure is further reduced due to oxidation of the porous metal. This leads to stronger decomposition of LSCF, associated with increased formation of $\mathrm{La}_{2} \mathrm{O}_{3}$, and therefore to higher failure rates. This is an important conclusion, which differs from the statement in the earlier work (51), where stresses due to phase changes along with increased sintering stresses were assumed to cause failure. Continued work with longer storage duration in ambient air therefore led to the modified deduction. The observed failure of the layers during storage occurred within the cathode layer, with a very thin layer of a few microns remaining attached to the electrolyte surface. HT-XRD analysis of these samples (not shown here) revealed a complete re-oxidation to LSCF structures also after hydroxide formation. This solely is a material property, but of minor importance for cathode fabrication, as the mechanical damage of the layer is an irreversible effect and will not be recovered. As described earlier, the phase decomposition and corresponding formation of $\mathrm{La}_{2} \mathrm{O}_{3}$ was more pronounced for LSC compared to LSCF if thermal treatment was conducted under the same conditions. LSC layers sintered under Ar on an MSC failed within one day of storage in ambient air. In the previous experiments it was noticed that the resulting formation of $\mathrm{La}_{2} \mathrm{O}_{3}$ is difficult to avoid as the sintering atmosphere cannot be 
controlled sufficiently. In order to overcome this restriction, the transformation of $\mathrm{La}_{2} \mathrm{O}_{3}$ to $\mathrm{La}(\mathrm{OH})_{3}$ due to the uptake of humidity needs to be prevented until the cell is put into operation. By heating in air during startup of the cell, the decomposition products will reversibly transform to the initial perovskite structure.

According to the presented HT-XRD results, re-oxidation of the cathode sintered ex situ in a separate thermal treatment under oxidizing conditions is not suitable as the required temperature is too high. At the obtained temperature of more than $700^{\circ} \mathrm{C}$, strong oxidation of the substrate and anode would occur. Re-oxidation experiments on printed layers on MSCs confirmed that a lower temperature is not sufficient for the reversible phase transformation.

A suitable procedure to prevent failure of the sintered cathodes was obtained by a combination of two approaches. First, using an increased Ar flux during sintering clearly reduces the decrease of the $\mathrm{p}_{\mathrm{O} 2}$. In our experimental setup, an argon flow of $185 \mathrm{Sml} / \mathrm{min}$ in the presence of ITM substrate led to a $\mathrm{p}_{\mathrm{O} 2}$ of $10^{-13}$ bar. By increasing the flow rate to $840 \mathrm{Sml} / \mathrm{min}$, values in the range of $10^{-9}-10^{-6}$ bar were achieved. Second, sealing of cells produced in this way in an air-tight foil pouch avoids contact with humid air during storage. In contrast to sintered cells stored under ambient air, sealed cells were able to be used for electrochemical characterization after several weeks of storage.

The presented results indicate that the developed ex situ sintering procedure is applicable to cells with LSCF cathodes if the sintered cells are not exposed to humidity from air. Attempts to apply ex situ sintering to LSC, however, are currently hindered as the stronger decomposition makes handling of the sintered cells quite difficult. Thus, cells fabricated ex situ with an LSC cathode are not sufficiently reliable so far. For this reason, LSC cathodes were fabricated in the present project by the conventional approach with in situ activation during the first hours of cell operation. Nevertheless, applying ex situ sintering to LSC cathodes is of great interest from an industrial point of view, as dimensional changes and reactivity will be reduced during cell operation. Therefore, this will be part of our future research.

\subsection{Electrochemical Performance of Cells with LSCF Cathodes Sintered Ex Situ}

The achieved reliable fabrication of LSCF cathodes sintered ex situ enabled the characterization of complete cells. LSCF cathodes were printed on MSC half-cells, sintered under $\operatorname{Ar}$ at $950^{\circ} \mathrm{C}$, and subsequently sealed in foil pouches. The pouches were opened immediately before the single-cell measurement to avoid a reaction with humidity from air. Upon heating to the sealing temperature of $850^{\circ} \mathrm{C}$, the reversible phase transformation takes place, as demonstrated in the HT-XRD results shown in Section 3.2. The measurements at JÜLICH and PSE revealed good electrochemical performance of the cells sintered ex situ. Current densities at a voltage of $0.7 \mathrm{~V}$ are slightly higher compared to state-of-the-art cells from PSE (26) which were activated in situ at $850{ }^{\circ} \mathrm{C}$ and measured in parallel as a reference (35). Furthermore, good agreement was obtained between the performance of cells measured at JÜLICH and at PSE in the case of similar gas flow rates. In Figure 6 I/V-curves measured with similar gas flow rates at PSE and 
JÜLICH are shown (raw data, no fitting). The almost linear appearance of the curves also in the high current regime indicates that pronounced concentration polarization was avoided at the present fuel/air utilizations of $25-30 \%$ and $50-55 \%$, respectively. The curves measured at PSE (Figure 6, left) show small fluctuations. This is assumed to result from the use of dry $\mathrm{H}_{2}$ as fuel, which might lead to fluctuations of the water vapor pressure at the anode side. The pronounced irregularities visible in the measurements conducted at JÜLICH (Figure 6, right) can be explained by insufficient sealing of the glass solder, as shown in Figure 7 (right). This might also be the reason for part spallation of the cathode of this cell, which was observed after demounting the sample from the test-rig. Performance data of the measured cells are summarized in Table 1. The current densities achieved at a cell voltage of $0.7 \mathrm{~V}$ are higher for the cell sintered ex situ compared to the reference cell over the whole temperature range. The observed performance increase was most pronounced at $750^{\circ} \mathrm{C}$, where the cell sintered ex situ reached a current density of $0.96 \mathrm{~A} / \mathrm{cm}^{2}$, compared to $0.82 \mathrm{~A} / \mathrm{cm}^{2}$ for the reference cell. Furthermore, no spallation of the cathode occurred after the single-cell measurement at PSE as shown in Figure 7 (left). This is a substantial improvement compared to standard cells, where spallation of large cathode areas has been regularly observed, which might lead to uncontrolled cell degradation during long-term operation. Thus, the presented results demonstrate a successful improvement in processing for LSCF cathodes.

\subsection{Electrochemical Performance of Cells with LSC Cathode Sintered In Situ}

MSCs with LSC cathodes were tested using the state-of-the-art procedure with in situ activation of the cathode at $850^{\circ} \mathrm{C}$ during the initial heating of the cell. As LSC, according to the literature (61), is expected to offer significantly increased cell performance, additional I/V curves were measured with increased flow rates in addition to the parameters used for LSCF. As the determined air utilization was rather high for LSCF, and a higher performing cathode will utilize more oxygen, the flow rate of air was increased in a larger proportion compared to the fuel. The results are presented in Figure 8. Initially, the $\mathrm{I} / \mathrm{V}$ curves of the MSC with LSC cathode are shifted to higher values in comparison to the cell with an LSCF cathode sintered ex situ. At high temperatures and high current densities, however, a stronger limitation can be observed. This limitation results in a performance of about $1.1 \mathrm{~A} / \mathrm{cm}^{2}$ at $0.7 \mathrm{~V}$ and a temperature of about $800{ }^{\circ} \mathrm{C}$, which is comparable to the performance obtained with an LSCF cathode, shown in Figure 6. A notable observation is that an obvious mass transfer limitation at high current densities can only be avoided with significantly increased gas flow rates. By increasing the $\mathrm{H}_{2}$ flow rate from 33 to $63 \mathrm{ml} /\left(\mathrm{min} \mathrm{cm}^{2}\right)$ and the air flow rate from 41 to $190 \mathrm{ml} /\left(\mathrm{min} \mathrm{cm}^{2}\right)$, the performance generally increased and limitation in the high current density region was reliably avoided. An increased cell temperature and comparatively low OCVs were measured, indicating leakages in the system. These leakages might originate from irregularities of the electrolyte or incomplete sealing. Therefore, the measured cell temperature was chosen as the real temperature of measurement. This higher temperature also contributes to an increase in performance, as the electrochemical processes are thermally activated. 
A slightly higher performance of cells with LSC cathodes was found by comparing the performance of the cells with LSC cathode and - as a reference - with LSCF cathodes. Both cells were activated in situ at $850^{\circ} \mathrm{C}$. The performance of these cells is summarized in Table 2. Approximately the same performance can be achieved at a temperature about $20^{\circ} \mathrm{C}$ lower than that needed for LSCF. Moreover, the influence of the high air flow rate leading to significant performance increase was observed to be much less pronounced for cells equipped with LSCF cathodes (not shown). This leads to the assumption that in the current cell design the PSE MSC is limited by the anode at low operating temperatures $\left(<750^{\circ} \mathrm{C}\right)$, whereas at high temperatures the cathode exhibits a stronger influence. A significant performance increase compared to the standard cell can be achieved by sintering the LSCF cathode before starting cell operation. Further improvement is possible by applying LSC as the cathode material. The issue of insufficient adherence of cathodes sintered in situ at $850^{\circ} \mathrm{C}$ seems less pronounced for LSC cathodes, but still exists. Figure 9 shows the LSC cathode on a button cell after operation. The onset of spallation can be observed on small areas and the imprint of the gold mesh is more pronounced than for the sintered LSCF cathode. Thus, the adherence of the LSC cathode appears to be better than for LSCF cathodes activated in situ but not as good as observed on LSCFs sintered ex situ.

\subsection{Microstructural Characterization}

SEM analysis of the tested cells was conducted on polished cross sections of embedded samples. When changing processing conditions, the influence of a thermal treatment under a certain atmosphere to other cell components, besides the cathode layer itself, always needs to be considered as well. Thermal expansion and CTE differences lead to stresses which might affect layer properties. Microstructural changes as well as oxidation of metallic components may occur during additional thermal treatments. The SEM analysis of a cell sintered ex situ did not reveal any obvious damage of the metal substrate, anode or electrolyte (Figure 10). The residual oxygen content in the Ar atmosphere, in theory, is sufficiently high to oxidize $\mathrm{Ni}$ and $\mathrm{Cr}$. After sintering though, only a slight oxidation of the free ITM surface at the edge of the treated cells was observed. This indicates that detrimental oxidation is avoided reliably as long as there is no significant flow of the gas through the porous structure. Another possible degradation mechanism might occur due to the low $\mathrm{p}_{\mathrm{O} 2}$ atmosphere during sintering. Under such conditions interactions of materials might change, as recently reported by Esposito et al. (62), who reported accelerated interdiffusion of ceria and zirconia variations at high temperature and low $p_{02}$. In the current state of microstructural analysis of sintered and tested cells, we did not observe indications for pronounced interdiffusions. This is expected to be less pronounced at the lower temperatures and higher oxygen contents applied here.

The images obtained from cells with LSCF cathodes sintered ex situ did not reveal notable differences compared to LSCF cathode structures sintered in ambient air. As expected, a finer microstructure resulting from the lower sintering temperature can be observed in Figure 11, compared to an ASC cathode sintered at $1040^{\circ} \mathrm{C}$, but no obvious features due to the different sintering atmosphere. The microstructure of a typical ASC cathode is 
shown in Figure 12. Details of the fabrication and ASC processing are given in (63). A significantly different microstructure was obtained from the LSC cathode which was activated in situ at $850^{\circ} \mathrm{C}$. As shown in Figure 13, the structure consists of much finer particles with less well-developed sintering necks. Whereas a well-connected network of particles was obtained in the case of the LSCF cathode sintered ex situ, the structure of the LSC cathode reveals small areas of connected particles which are hardly connected to each other. In comparison, Figure 14 shows the cross sectional image of a standard LSCF cathode which was sintered in situ at $850^{\circ} \mathrm{C}$, and operated for $500 \mathrm{~h}$. The microstructure appears more homogeneous but also reveals very fine particles with small sintering necks. Details of this experiment can be found in (3).

The electrochemical results (Sections 3.4. and 3.5.) can be related to the microstructure of the cathodes. The LSCF cathode sintered ex situ reveals a homogeneous microstructure, which is finer than typical ASC cathodes, but has a generally similar appearance. The good performance achieved is therefore in agreement with the known high performance in the ASC setup. The LSC cathode, which was sintered in situ at $850^{\circ} \mathrm{C}$, however, reveals a microstructure which appears prone to mechanical failure as well as to limitation phenomena due to mass transfer or current constriction. This is due to the very fine structure with only weak connections between the particles. Therefore, especially at high current densities, current constriction can emerge as the current needs to pass the small sintering necks. Moreover, the gas supply might be restricted by the fine microstructure with small pores. This observation can explain the stronger limitation of the cell with LSC cathode, compared to the cells with LSCF cathode.

\section{Conclusion}

Improved processing of cathodes for MSCs was the aim of the work presented here. LSCF and LSC were chosen as candidates due to their good performance, which is known from their application in anode-supported cells. An ex situ sintering procedure was investigated in order to increase the adherence between cathode and electrolyte by applying a higher sintering temperature compared to state-of-the-art in situ activation at $850{ }^{\circ} \mathrm{C}$. For this sintering step, the metallic substrate and the Ni particles of the anode must be protected from oxidation. On the other hand, strongly reducing atmospheres have to be avoided due to the limited phase stability of the LSCF perovskite at low $\mathrm{p}_{\mathrm{O} 2}$ and high temperature. From the initial experiments, ex situ sintering at $950{ }^{\circ} \mathrm{C}$ under $\mathrm{Ar}$ atmosphere was found to be applicable to LSCF, whereas the lower thermochemical stability of LSC increases the susceptibility to failure due to strong phase decomposition. Therefore, ex situ sintering was performed only for MSCs with LSCF cathodes, but was not applied to MSCs with LSC cathodes.

The sintering conditions led to a phase decomposition of the LSCF perovskite phase, which is reversible upon heating in air at $\mathrm{T}>750{ }^{\circ} \mathrm{C}$. The formation of $\mathrm{La}_{2} \mathrm{O}_{3}$ was found to be critical regarding the cathode layer stability if the cell is stored in ambient air. This is due to a volume expansion resulting from the hygroscopic behavior of $\mathrm{La}_{2} \mathrm{O}_{3}$ and the formation of $\mathrm{La}(\mathrm{OH})_{3}$ on exposure to humidity from air. By sealing the sintered cell in a foil 
pouch for storage, cathode failure was prevented as the cell was not exposed to humidity from the ambient air. Electrochemical characterization of the cells sintered ex situ revealed a significant performance increase in comparison to state-of-the-art MSCs (activated in situ at $850^{\circ} \mathrm{C}$ ) in the investigated temperature range of 650 to $850^{\circ} \mathrm{C}$. At $750{ }^{\circ} \mathrm{C}$, performance increased by about $17 \%\left(0.96 \mathrm{~A} / \mathrm{cm}^{2}\right.$ vs. $0.82 \mathrm{~A} / \mathrm{cm}^{2}$ at a cell voltage of $0.7 \mathrm{~V})$. Furthermore, a significantly improved adherence of the cathode was observed. A reliably adhering cathode layer is assumed to considerably decrease the cathode-related degradation of MSCs as loss of active cell area during operation is prevented.

The LSC was implemented as an MSC cathode using the state-of-the-art activation procedure at $850{ }^{\circ} \mathrm{C}$ during initial heating of the cell. In the single-cell measurements of cells with LSC cathodes, a pronounced performance increase was obtained the high operating temperatures of $\mathrm{T}>750^{\circ} \mathrm{C}$ if mass transfer limitation was eliminated by using high gas flow rates $\left(63 \mathrm{ml} /\left(\mathrm{cm}^{2} \mathrm{~min}\right) \mathrm{H}_{2} ; 190 \mathrm{ml} /\left(\mathrm{cm}^{2} \mathrm{~min}\right)\right.$ air instead of 33 and $41 \mathrm{ml} /\left(\mathrm{cm}^{2} \mathrm{~min}\right)$, respectively). A current density of $1.37 \mathrm{~A} / \mathrm{cm}^{2}$ at $0.7 \mathrm{~V}$ and $745^{\circ} \mathrm{C}$ was achieved under these conditions. At lower temperatures and lower gas flow rates the performance of cells equipped with LSC cathodes revealed only a slight improvement compared to LSCF. In this case, similar current densities were achieved with LSC cathodes at a temperature about $20^{\circ} \mathrm{C}$ lower than with LSCF, e.g. $0.86 \mathrm{~A} / \mathrm{cm}^{2}$ at $731^{\circ} \mathrm{C}$ vs. $0.85 \mathrm{~A} / \mathrm{cm}^{2}$ at $750{ }^{\circ} \mathrm{C}$ for LSCF.

From the results obtained in this study, it can be concluded that the ex situ sintering process and protection from humidity during subsequent storage of LSCF cathodes on MSCs successfully addressed the cathode issues considered. The resulting considerable improvement in ruggedness is expected to accordingly increase the durability of these cathodes. The electrochemical activity of the sintered cathode was confirmed in single-cell measurements. Increased performance at T $>750{ }^{\circ} \mathrm{C}$ of cells with LSC cathodes revealed the potential of LSC for future experiments. The strong limitation of LSC cathodes detected indicates that the cathode microstructure exerts an influence. A finer structure due to the lower activation temperature might cause mass transfer limitation and/or current constriction at high current densities. The less pronounced difference of LSC and LSCF at temperatures lower than $750^{\circ} \mathrm{C}$ indicates a possible limitation originating from the $\mathrm{Ni} / 8 \mathrm{YSZ}$ anode. In the temperature range below $750^{\circ} \mathrm{C}$, both cathode materials might exhibit sufficient catalytic activity and the cell is limited by the anode reaction.

Further experiments will focus on the long-term performance of cells with LSCF cathodes sintered ex situ as well as on further optimization of the processing of LSC cathodes. Moreover, an improvement of the cathode layer stability (e.g. possibility of storage in ambient conditions) of MSCs sintered ex situ is of great interest in order to simplify handling of the sintered cells. Additional efforts might be necessary to assess the potential to enhance the performance by microstructure optimization. 


\section{Acknowledgements}

The authors thank Mrs. B. Bär and Mr. S. Hummel for conducting the electrochemical tests at IEK-9 in JÜLICH and at Plansee SE, respectively, Dr. Y.J. Sohn for conducting XRD measurements, and Dr. D. Sebold for SEM analysis. Furthermore, funding of the Christian Doppler Laboratory by the Austrian Bundesministerium für Wissenschaft, Forschung und Wirtschaft (BMWFW) and by the industrial partners is gratefully acknowledged.

1. A. B. Stambouli and E. Traversa, Renewable and Sustainable Energy Reviews, 6, 433 (2002).

2. S. C. Singhal, High temperature solid oxide fuel cells : fundamentals, design and applications, p. XIII, Elsevier, Oxford (2003).

3. D. Roehrens, O. Büchler, D. Sebold, M. Kappertz, W. Schafbauer, T. Franco, N. H. Menzler and H. P. Buchkremer, ECS Transactions, 57, 665 (2013).

4. B. J. McKenna, N. Christiansen, R. Schauperl, P. Prenninger, J. Nielsen, P. Blennow, T. Klemensø, S. Ramousse, A. Kromp and A. Weber, Fuel Cells, 13, 592 (2013). 5. M. Haydn, K. Ortner, T. Franco, S. Uhlenbruck, N. H. Menzler, D. Stöver, G. Bräuer, A. Venskutonis, L. S. Sigl, H.-P. Buchkremer and R. Vaßen, Journal of Power Sources, 256, 52 (2014).

6. S. C. Singhal, Solid State lonics, 152-153, 405 (2002).

7. R. A. George, Journal of Power Sources, 86, 134 (2000).

8. V. V. Kharton, F. M. B. Marques and A. Atkinson, Solid State Ionics, 174, 135 (2004).

9. J. W. Fergus, Journal of Power Sources, 162, 30 (2006).

10. F. Tietz, H. P. Buchkremer and D. Stöver, Solid State Ionics, 152-153, 373 (2002).

11. A. Weber and E. Ivers-Tiffée, Journal of Power Sources, 127, 273 (2004).

12. D. J. L. Brett, A. Atkinson, N. P. Brandon and S. J. Skinner, Chemical Society Reviews, 37, 1568 (2008).

13. N. Christiansen, J. B. Hansen, H. Holm-Larsen, M. Juel Jorgensen, M. Wandel, P. Vang Hendriksen, A. Hagen and S. Ramousse, ECS Transactions, 25, 133 (2009).

14. V. A. C. Haanappel and M. J. Smith, Journal of Power Sources, 171, 169 (2007).

15. N. H. Menzler, F. Tietz, S. Uhlenbruck, H. Buchkremer and D. Stöver, J Mater Sci, 45, 3109 (2010).

16. F. Tietz, Q. Fu, V. A. C. Haanappel, A. Mai, N. H. Menzler and S. Uhlenbruck, International Journal of Applied Ceramic Technology, 4, 436 (2007).

17. L. Blum, H. P. Buchkremer, S. Gross, A. Gubner, L. G. J. de Haart, H. Nabielek, W. J. Quadakkers, U. Reisgen, M. J. Smith, R. Steinberger-Wilckens, R. W. Steinbrech, F. Tietz and I. C. Vinke, Fuel Cells, 7, 204 (2007).

18. L. Blum, L. G. J. de Haart, J. Malzbender, N. H. Menzler, J. Remmel and R. Steinberger-Wilckens, Journal of Power Sources, 241, 477 (2013).

19. L. Blum, P. Batfalsky, Q. Fang, L. G. J. de Haart, J. Malzbender, N. Margaritis, N. H. Menzler and R. Peters, Journal of The Electrochemical Society, 162, F1199 (2015).

20. N. P. Brandon, D. Corcoran, D. Cummins, A. Duckett, K. El-Khoury, D. Haigh, R. Leah, G. Lewis, N. Maynard, T. McColm, R. Trezona, A. Selcuk and M. Schmidt, J. of Materi Eng and Perform, 13, 253 (2004).

21. M. C. Tucker, Journal of Power Sources, 195, 4570 (2010).

22. A. Ansar, P. Szabo, J. Arnold, Z. Ilhan, D. Soysal, R. Costa, A. Zagst, M. Gindrat and T. Franco, ECS Transactions, 35, 147 (2011). 
23. P. Bance, N. P. Brandon, B. Girvan, P. Holbeche, S. O'Dea and B. C. H. Steele, Journal of Power Sources, 131, 86 (2004).

24. P. Blennow, B. R. Sudireddy, A. H. Persson, T. Klemensø, J. Nielsen and K. Thydén, Fuel Cells, n/a (2013).

25. I. Villarreal, M. Rivas, L. M. Rodriguez-Martinez, L. Otaegi, A. Zabala, N. Gomez, M. Alvarez, I. Antepara, N. Arizmendiarrieta, J. Manzanedo, M. Olave, A. Urriolabeitia, N. Burgos, F. Castro and A. Laresgoiti, ECS Transactions, 25, 689 (2009).

26. T. Franco, M. Haydn, R. Mücke, A. Weber, M. Rüttinger, O. Büchler, S. Uhlenbruck, N. H. Menzler, A. Venskutonis and L. S. Sigl, ECS Transactions, 35, 343 (2011).

27. M. Rüttinger, R. Mücke, T. Franco, O. Büchler, N. H. Menzler and A. Venskutonis, ECS Transactions, 35, 259 (2011).

28. Y. B. Matus, L. C. De Jonghe, C. P. Jacobson and S. J. Visco, Solid State Ionics, 176, Start Page: 443 (2005).

29. J. Rechberger and P. Prenninger, SAE Technical Papers, Commercial Vehicle Engineering Congress and Exhibition (2007).

30. T. Franco, M. Brandner, M. Rüttinger, G. Kunschert, A. Venskutonis and L. Sigl, ECS Transactions, 25, 681 (2009).

31. K. Eguchi, H. Kojo, T. Takeguchi, R. Kikuchi and K. Sasaki, Solid State Ionics, 152-153, 411 (2002).

32. T. Franco, M. Haydn, A. Weber, W. Schafbauer, L. Blum, U. Packbier, D. Roehrens, N. H. Menzler, J. Rechberger, A. Venskutonis, L. S. Sigl and H. P. Buchkremer, ECS Transactions, 57, 471 (2013).

33. V. A. Rojek-Wöckner, A. K. Opitz, M. Brandner, J. Mathé and M. Bram, Journal of Power Sources, 328, 65 (2016).

34. M. Gerstl, A. Nenning, R. Iskandar, V. Rojek-Wöckner, M. Bram, H. Hutter and A. Opitz, Materials, 9, 649 (2016).

35. V. A. Rojek-Wöckner, Entwicklung und Charakterisierung von Nickel/GadoliniumCeroxid-basierten Anoden für die metallgestützte Festoxid-Brennstoffzelle, in (2017).

36. N. Jordan, W. Assenmacher, S. Uhlenbruck, V. A. C. Haanappel, H. P. Buchkremer, D. Stöver and W. Mader, Solid State Ionics, 179, 919 (2008).

37. M. Haydn, K. Ortner, M. Rüttinger, T. Franco, T. Jung and S. Uhlenbruck, Mehrlagige Schichtanordnung für einen Festkörperelektrolyt, in, Google Patents (2016).

38. N. Q. Minh and T. Takahashi, in Science and Technology of Ceramic Fuel Cells, p. 117, Elsevier Science Ltd, Oxford (1995).

39. M. Al Daroukh, V. V. Vashook, H. Ullmann, F. Tietz and I. Arual Raj, Solid State lonics, 158, 141 (2003).

40. S.-i. Hashimoto, Y. Fukuda, M. Kuhn, K. Sato, K. Yashiro and J. Mizusaki, Solid State lonics, 181, 1713 (2010).

41. C. Niedrig, S. F. Wagner, W. Menesklou and E. Ivers-Tiffée, Solid State lonics (2014).

42. T. Klemensø, J. Nielsen, P. Blennow, Å. H. Persson, T. Stegk, B. H. Christensen and S. Sønderby, Journal of Power Sources, 196, 9459 (2011).

43. J. Jeong, S.-W. Baek and J. Bae, Journal of Power Sources, 250, 98 (2014).

44. J. Nielsen, P. Hjalmarsson, M. H. Hansen and P. Blennow, Journal of Power Sources, 245, 418 (2014).

45. M. C. Tucker, ECS Transactions, 78, 2015 (2017).

46. V. V. Krishnan, Wiley Interdisciplinary Reviews: Energy and Environment, n/a (2017).

47. P. Kountouros, R. Förthmann, A. Naoumidis, G. Stochniol and E. Syskakis, Ionics, 1, 40 (1995). 
48. A. Mai, Katalytische und elektrochemische Eigenschaften von eisen- und kobalthaltigen Perowskiten als Kathoden für die oxidkeramische Brennstoffzelle (SOFC), Forschungszentrum Jülich, Zentralbibliothek, Jülich (2004).

49. M. Haydn, T. Franco, R. Mücke, M. Rüttinger, N. H. Menzler, A. Weber, A. Venskutonis and L. S. Sigl, in Euro PM 2012 (2012).

50. M. Haydn, K. Ortner, T. Franco, N. H. Menzler, A. Venskutonis and L. S. Sigl, Powder Metallurgy, 56, 382 (2013).

51. D. Udomsilp, D. Roehrens, N. H. Menzler, A. K. Opitz, O. Guillon and M. Bram, Materials Letters, 192, 173 (2017).

52. J. Ovenstone, J. S. White and S. T. Misture, Journal of Power Sources, 181, 56 (2008).

53. J. Ovenstone, J.-I. Jung, J. S. White, D. D. Edwards and S. T. Misture, Journal of Solid State Chemistry, 181, 576 (2008).

54. L. W. Tai, M. M. Nasrallah, H. U. Anderson, D. M. Sparlin and S. R. Sehlin, Solid State lonics, 76, 273 (1995).

55. L. W. Tai, M. M. Nasrallah and H. U. Anderson, Journal of Solid State Chemistry, 118, 117 (1995).

56. A. N. Petrov, V. A. Cherepanov and A. Y. Zuev, J Solid State Electrochem, 10, 517 (2006).

57. M. Kuhn, S. Hashimoto, K. Sato, K. Yashiro and J. Mizusaki, Solid State Ionics, 241, 12 (2013).

58. M. Kuhn, S. Hashimoto, K. Sato, K. Yashiro and J. Mizusaki, Journal of Solid State Chemistry, 197, 38 (2013).

59. Y. Zhao, Materials, 5, 1413 (2012).

60. J. Seeger, Entwicklung protonenleitender Werkstoffe und Membranen auf Basis von Lanthan-Wolframat für die Wasserstoffabtrennung aus Gasgemischen [E-Book], Forschungszentrum Jülich, Zentralbibliothek, Jülich (2013).

61. F. Han, R. Mücke, T. Van Gestel, A. Leonide, N. H. Menzler, H. P. Buchkremer and D. Stöver, Journal of Power Sources, 218, 157 (2012).

62. V. Esposito, D. W. Ni, D. Marani, F. Teocoli, K. T. Sune Thyden, D. Z. De Florio and F. C. Fonseca, Journal of Materials Chemistry A, 4, 16871 (2016).

63. S. Uhlenbruck, N. Jordan, D. Sebold, H. P. Buchkremer, V. A. C. Haanappel and D. Stöver, Thin Solid Films, 515, 4053 (2007).

64. M. Bram, D. Udomsilp, D. Roehrens, N. H. Menzler, A. K. Opitz, L. G. J. de Haart and O. Guillon, ECS Transactions, 78, 709 (2017). 


\section{Figures}

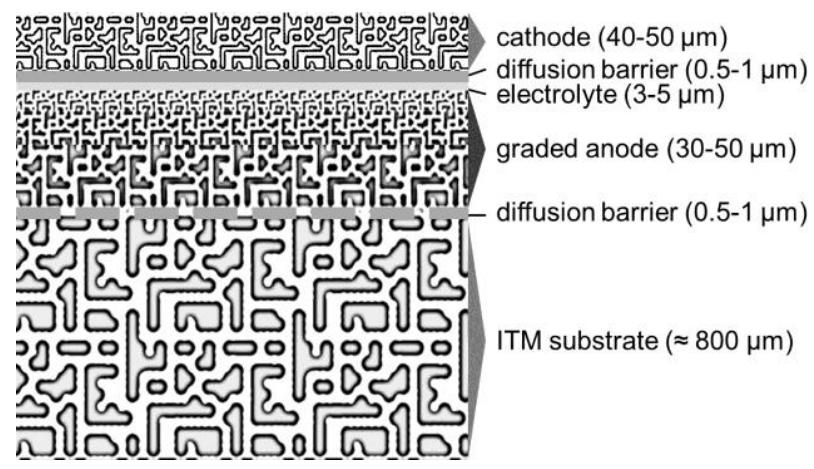

Figure 1: Schematic of the PSE MSC setup. Adapted from (49)

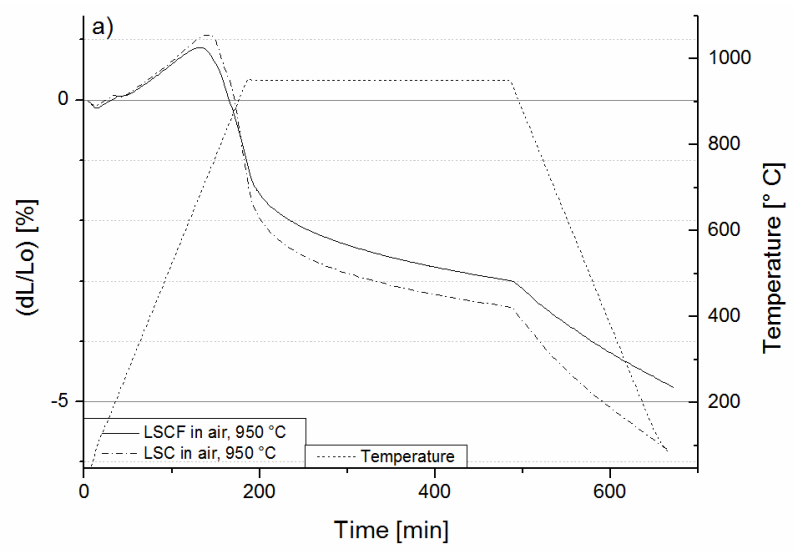

Figure 2: Dilatometry measurements - comparison of shrinkage of LSC and LSCF during sintering at $950{ }^{\circ} \mathrm{C}$ in ambient air. 


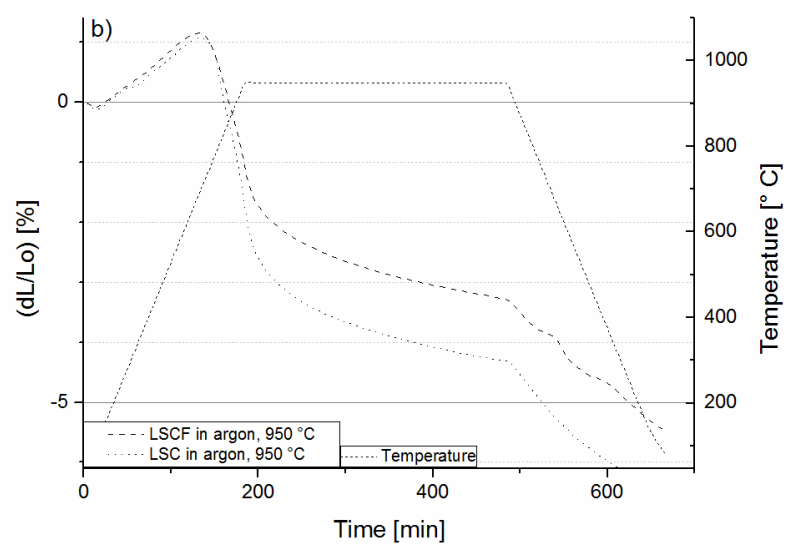

Figure 3: Dilatometry measurements - comparison of shrinkage of LSC and LSCF during sintering at $950^{\circ} \mathrm{C}$ in argon.

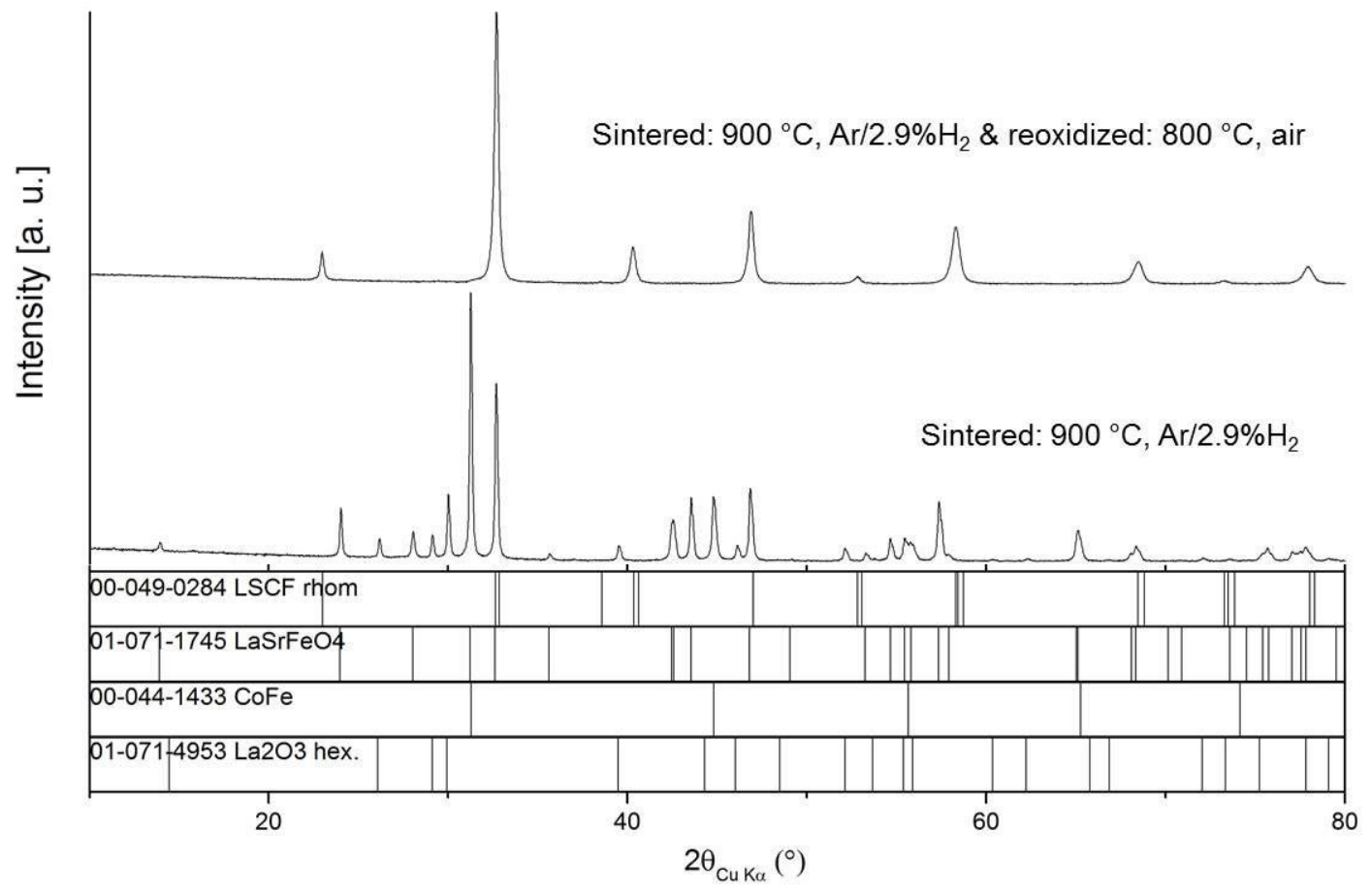

Figure 4: XRD analysis of a screen-printed LSCF layer on an electrolyte substrate after sintering at $900{ }^{\circ} \mathrm{C}$ under $\mathrm{Ar} / 2.9 \% \mathrm{H}_{2}$ (bottom) and subsequent re-oxidation at $800{ }^{\circ} \mathrm{C}$ in ambient air (top). 


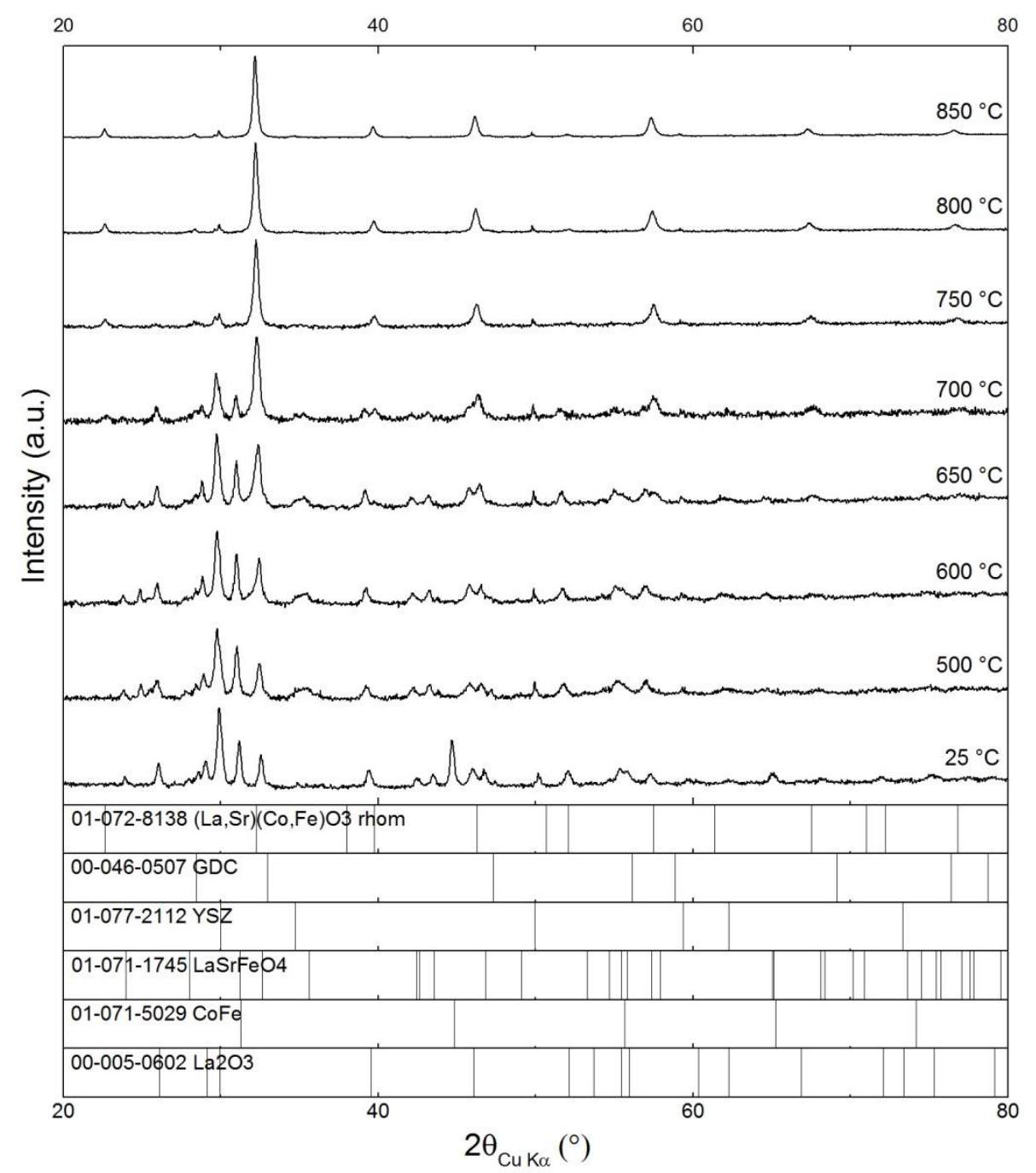

Figure 5: In situ observation of the reversible phase transformation of LSCF by HT-XRD. First measurement conducted at RT (bottom) after thermal treatment for $3 \mathrm{~h}$ at $950{ }^{\circ} \mathrm{C}$ in $\mathrm{Ar} / \mathrm{H}_{2}$. Subsequent measurements were performed by increasing the temperature to $500^{\circ} \mathrm{C}$ and further steps of $50^{\circ} \mathrm{C}$ starting from $600{ }^{\circ} \mathrm{C}$. 

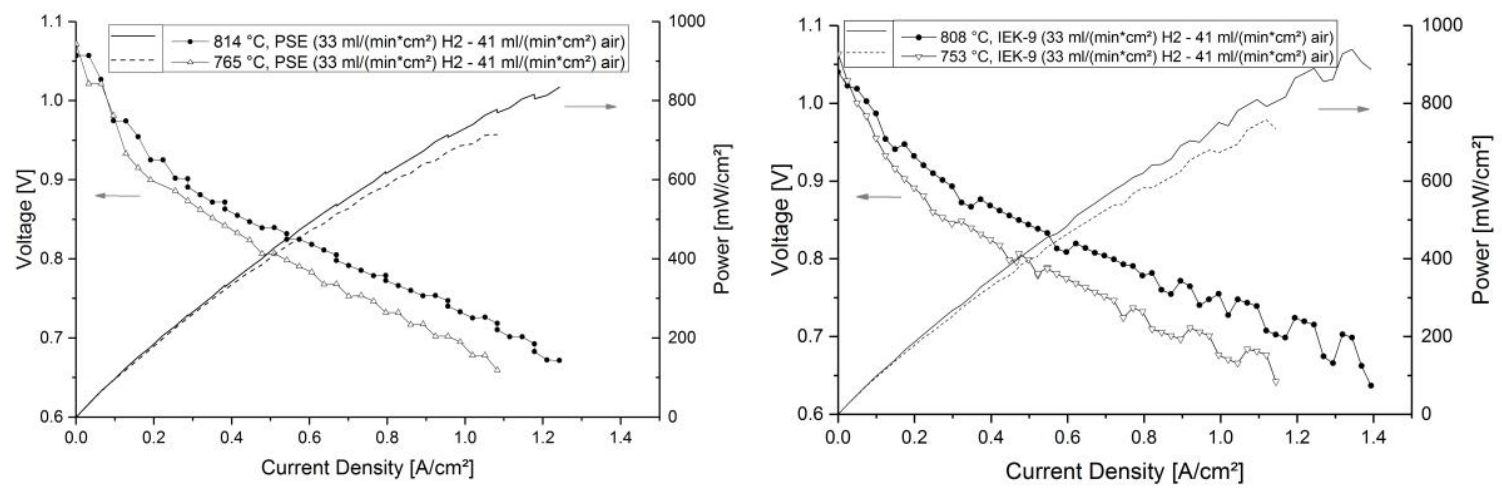

Figure 6: I/V-curves of MSCs with LSCF cathodes sintered ex situ, measured at PSE (left) and JÜLICH (right (64)). Gas supply: $33 \mathrm{ml} /\left(\operatorname{min~} \mathrm{cm}^{2}\right) \mathrm{H}_{2}, 41 \mathrm{ml} /\left(\operatorname{min~} \mathrm{cm}^{2}\right)$ air.
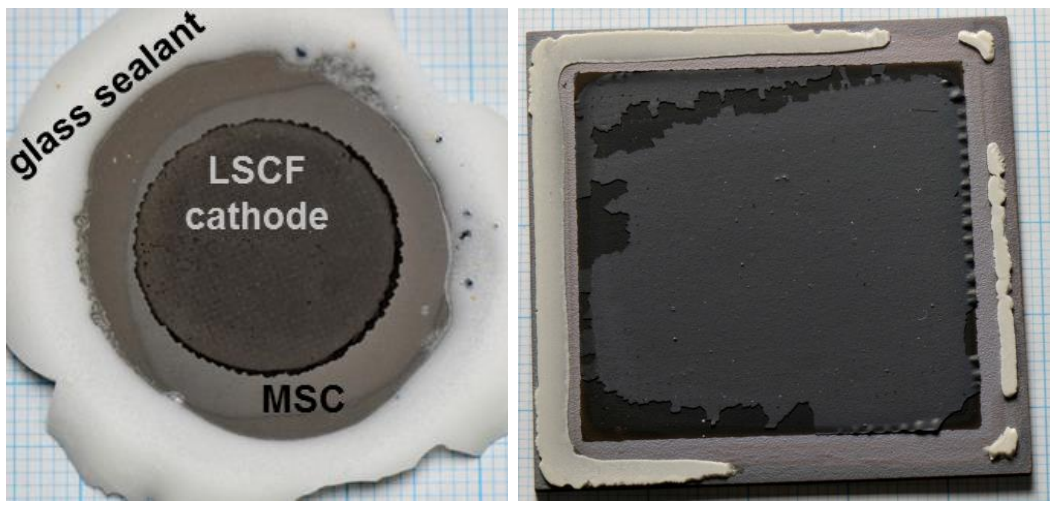

Figure 7: MSCs with LSCF cathodes sintered ex situ after single-cell measurements. Tests performed on cells with $3.14 \mathrm{~cm}^{2}$ active cathode area at PSE (left) and $16 \mathrm{~cm}^{2}$ active area at JÜLICH (right). 

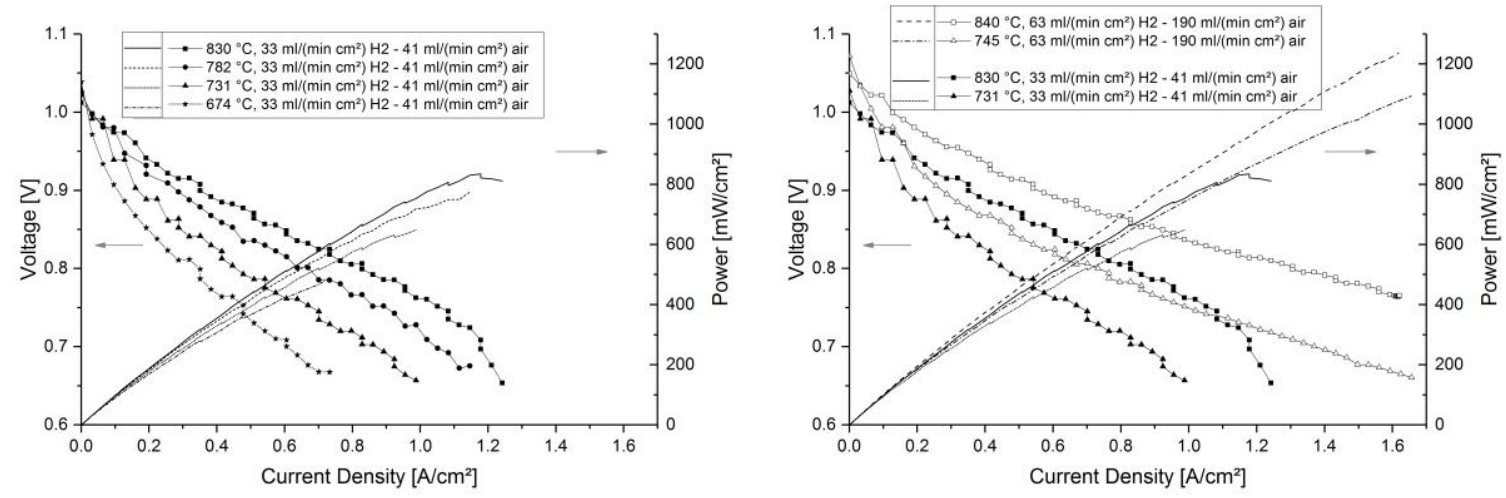

Figure 8: I/V-curves of MSC button cell with $20 \mathrm{~mm} \varnothing$ LSC cathode, measured at PSE.

Left: gas flow rates of $33 \mathrm{ml} /\left(\min \mathrm{cm}^{2}\right) \mathrm{H}_{2} \& 41 \mathrm{ml} /\left(\operatorname{min~} \mathrm{cm}^{2}\right)$ air (solid symbols); and right: comparison with $63 \mathrm{ml} /\left(\operatorname{min~} \mathrm{cm}^{2}\right) \mathrm{H}_{2} \& 190 \mathrm{ml} /\left(\operatorname{min~} \mathrm{cm}^{2}\right)$ air (open symbols)

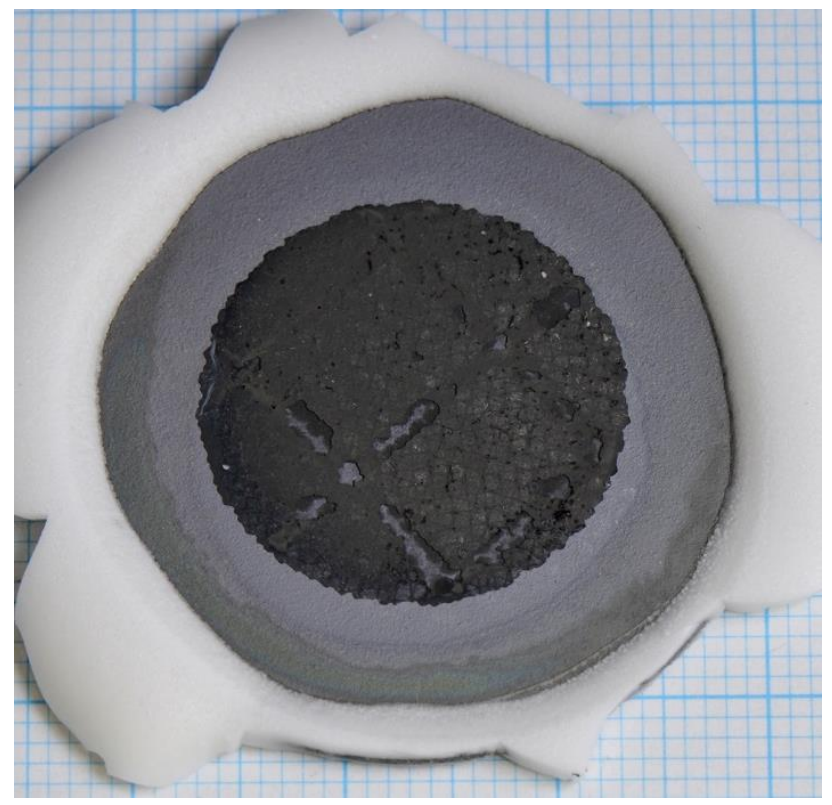

Figure 9: MSC button cell with $20 \mathrm{~mm} \varnothing$ LSC cathode, after single cell measurement at PSE. 


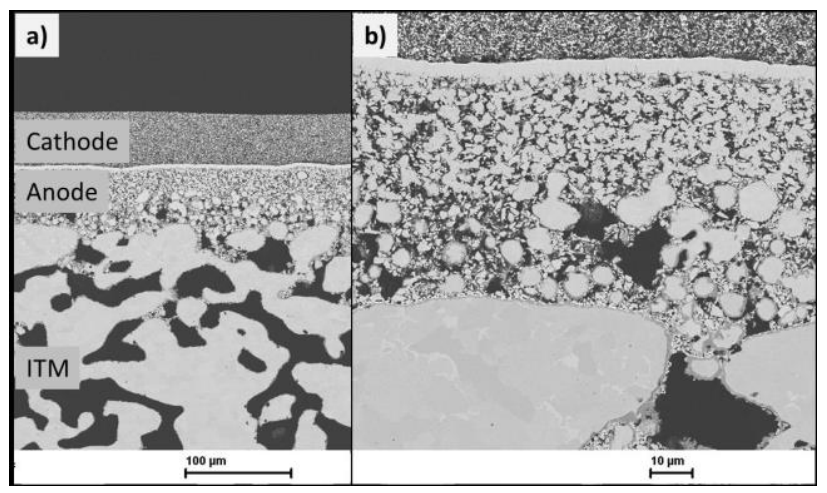

Figure 10: SEM cross sectional image of a MSC after ex situ sintering (not tested) in two magnifications.

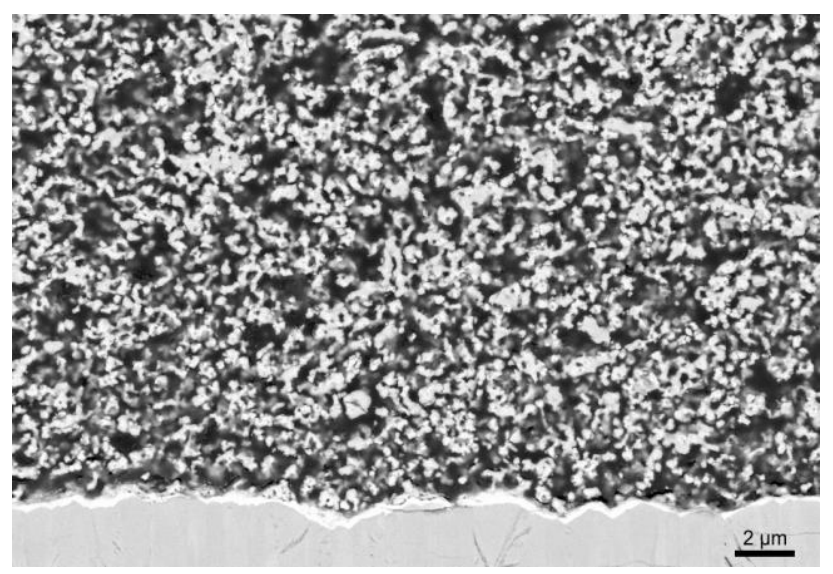

Figure 11: SEM image of a cross section of an MSC with LSCF cathode sintered ex situ after operation. 


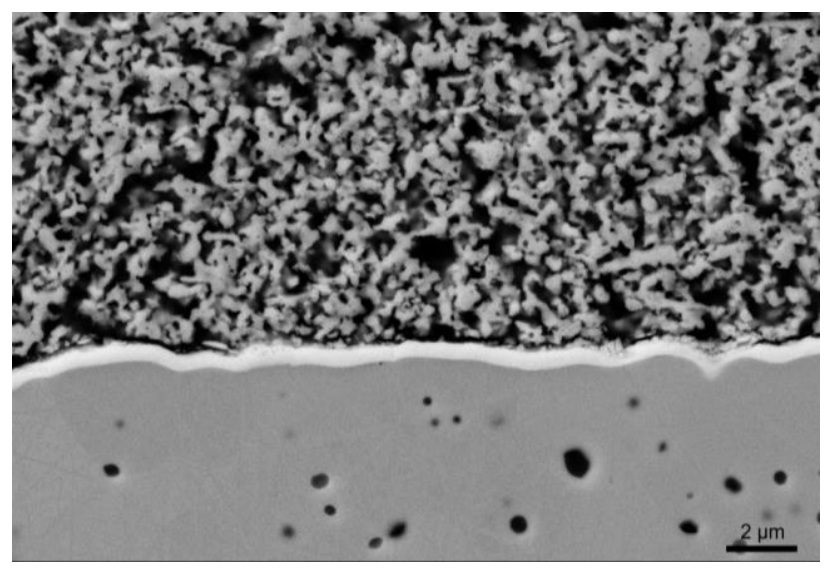

Figure 12: SEM image of a JÜLICH ASC with LSCF cathode sintered at $1040^{\circ} \mathrm{C}$.

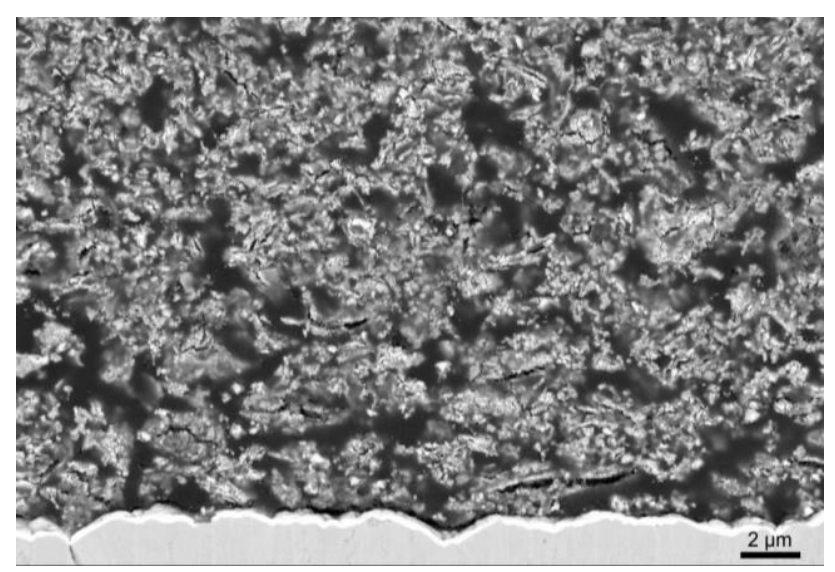

Figure 13: SEM image of a cross section of an MSC with LSC cathode sintered in situ at $850^{\circ} \mathrm{C}$ after operation. 


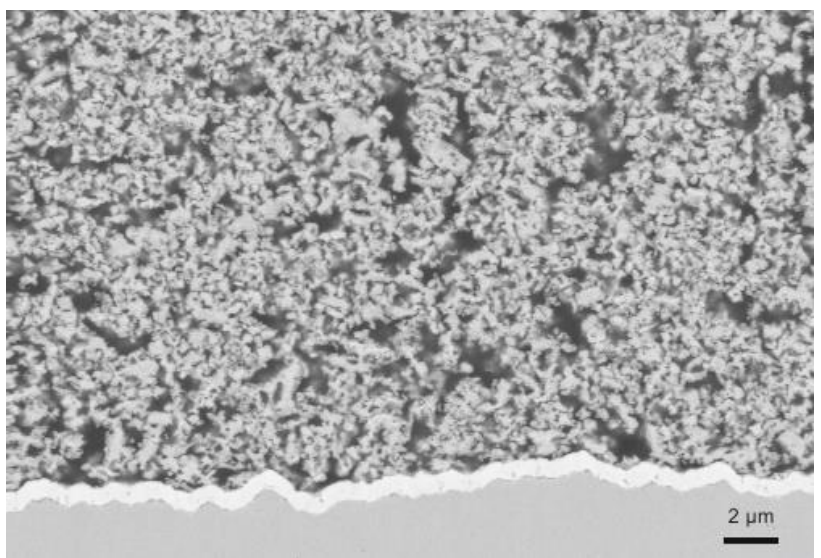

Figure 14: SEM image of a PSE MSC with LSCF cathode sintered in situ at $850{ }^{\circ} \mathrm{C}$ after operation. 


\section{Tables}

Table 1: Comparison of OCV and current density at a cell voltage of $0.7 \mathrm{~V}$ of an MSC sintered ex situ and the state-of-the-art MSC. $16 \mathrm{~cm}^{2}$ active cell area cells, both measured at IEK-9, JÜLICH, using $\mathrm{H}_{2} / 3 \% \mathrm{H}_{2} \mathrm{O}$ as fuel and air as oxidant.

\begin{tabular}{|c|c|c|c|c|}
\hline \multirow[b]{2}{*}{$\mathrm{T}_{\text {furnace }}\left[{ }^{\circ} \mathbf{C}\right]$} & \multicolumn{2}{|c|}{$\begin{array}{l}\text { MSC sintered ex situ } \\
\text { (developed in this work) }\end{array}$} & \multicolumn{2}{|c|}{$\begin{array}{l}\text { Reference: PSE standard cell } \\
\text { (activated in situ at } 850^{\circ} \mathrm{C} \text { ) (35) }\end{array}$} \\
\hline & OCV [V] & $\begin{array}{l}\mathbf{j}\left[\mathrm{A} / \mathbf{c m}^{2}\right] \\
@ 0.7 \mathrm{~V}\end{array}$ & OCV [V] & $\begin{array}{l}\mathbf{j}\left[\mathbf{A} / \mathbf{c m}^{2}\right] \\
@ 0.7 \mathrm{~V}\end{array}$ \\
\hline 850 & 1.04 & 1.30 & 1.04 & 1.20 \\
\hline 800 & 1.04 & 1.15 & 1.05 & 1.07 \\
\hline 750 & 1.06 & 0.96 & 1.07 & 0.82 \\
\hline 700 & 1.07 & 0.60 & 1.07 & 0.55 \\
\hline 650 & 1.07 & 0.35 & 1.07 & 0.34 \\
\hline
\end{tabular}


Table 2: Comparison of OCV and current density at a cell voltage of $0.7 \mathrm{~V}$ of an MSC with LSC cathode activated in situ and state-of-the-art MSC with LSCF cathode. Differences in the cell temperature are assumed to be caused by slight leakages due to irregularities of the electrolyte or imperfect sealing of the cell with LSC cathode.

\begin{tabular}{|c|c|c|c|c|c|}
\hline \multirow[b]{2}{*}{$\mathbf{T}_{\text {cell }}\left[{ }^{\circ} \mathbf{C}\right]$} & \multicolumn{2}{|c|}{$\begin{array}{l}\text { MSC with LSC cathode } \\
\text { sintered in situ at } 850^{\circ} \mathrm{C}\end{array}$} & \multirow[b]{2}{*}{$\mathbf{T}_{\text {furnace }}\left[{ }^{\circ} \mathrm{C}\right]$} & \multicolumn{2}{|c|}{$\begin{array}{l}\text { PSE standard cell } \\
\text { (activated in situ at } 850^{\circ} \mathrm{C} \text { ) }\end{array}$} \\
\hline & OCV [V] & $\begin{array}{l}\mathbf{j}\left[\mathbf{A} / \mathbf{c m}^{2}\right] \\
@ 0.7 \mathrm{~V}\end{array}$ & & $\mathrm{OCV}[\mathrm{V}]$ & $\begin{array}{l}\mathrm{j}\left[\mathbf{A} / \mathbf{c m}^{2}\right] \\
@ 0.7 \mathrm{~V}\end{array}$ \\
\hline 830 & 1.01 & 1.18 & 850 & 1.04 & 1.20 \\
\hline 782 & 1.02 & 1.05 & 800 & 1.05 & 1.07 \\
\hline 731 & 1.03 & 0.86 & 750 & 1.07 & 0.82 \\
\hline 674 & 1.04 & 0.61 & 700 & 1.07 & 0.55 \\
\hline
\end{tabular}

